\title{
Accounting Information:
}

\section{Which Information Attracts Investors Attention First?}

\author{
Ahmad N. Obaidat ${ }^{1}$ \\ ${ }^{1}$ Accounting Department, Business Faculty, Tafila Technical University, Jordan \\ Correspondence: Ahmad N. Obaidat, Accounting Department, Business Faculty, Tafila Technical University, P. O. \\ Box 179, Tafila 66110, Jordan, Tel: 962-778-251-525
}

Received: July 13, 2016

doi:10.5430/afr.v5n3p107
Accepted: July 21, 2016

Online Published: August 6, 2016

\begin{abstract}
This study extends Obaidat (2016) and Mohan \& John (2011) studies by investigating the accounting information that is considered more value relevant for individual investors in Amman Stock Exchange (ASE), emphasizing earning and cash flows information. In addition, the study examined if investors have the time and abilities to assess the accounting information. Finally, this study measured the degree of consensus among different types of investors concerning the issues investigated. The results indicated that investors perceive all accounting information to be value relevant and considered it to be complementary to each other, where the most value relevant information was the financial risk followed by previous earning, liquidity, expected earning, and market stock price. The results indicated that the value relevance of earning information is superior to the value relevance of cash flow information. The study documented that investors have the time and abilities to assess the value relevance of accounting information.
\end{abstract}

Keywords: Accounting information, Value relevance, Individual investors, Amman Stock Exchange (ASE), Earning, Cash flows

\section{Introduction}

In the conceptual framework for financial reporting, the International Accounting Standards Board (IASB) and the Financial Accounting Standard Board (FASB) stated that the primary objective of financial reporting is to provide useful information about the reporting entity to users, including investors, to enable them make rational decisions. But to be useful, accounting information should be characterized by essential characteristics. Among them is relevance. Most of the previous studies about the relevance of accounting information found a positive relationship between the information value relevance and making rational decisions (e.g., El Shamy \& Kayed 2005, Bhattacharya et al. 2010, Jianu et al. 2014, Farj et al. 2016). IASB and FASB in their effort to harmonize the accounting standards agreed on the definition of the relevant information, and defined it as "Relevant financial information is capable of making a difference in the decisions made by users." (IFRS 2015, FASB 2010). Other definitions and explanations of value relevance are found in accounting literatures, for example, Francis \& Schipper (1999) stated that "value relevance is measured by the ability of financial statement information to capture or summarize information, regardless of source, that affects share values". Hellström (2006) stated that "from the investors' perspective, relevant information is information which contributes to their equity investment decisions". Panagiotis \& Dimitrios (2009) defined it as "the ability of financial statements to summarize valuable information that affect stock price movements and assist investors to assess the value of the firm". Ebaid (2012) stated that "an accounting amount will be value-relevant only if the amount reflects information relevant to investors in valuing the firm and is measured reliably enough to be reflected in share prices". Recently, Huian (2015) stated that "for an investor, accounting information is value relevant if it is reflected in stock prices and/or stock returns".

Investigating the value relevance of accounting information for investment decisions has become a very important issue in accounting literature and there have been very extensive studies concerning this issue during the last decade and this is attributed to many reasons such as: first, Investors are considered as one of the most important groups of decision makers that use accounting information to value firms (El Shamy \& Kayed, 2005); second, one of the most important sources that provide investors with different types of information that help them choose among alternatives is the financial statement information (Al-Ajmi, 2009); third, the rise of new theories, new techniques, 
and new investor perspectives (Menaje, 2012); fourth, disclosure of relevant accounting information protects the investors, and thereby enhances the investors confidence in the market, so it is essential to maintain an efficient market system (Farj et al., 2016).

But the reality that accounting provides investors with value relevant information to make buying, holding, and selling decisions of stocks is questionable. Bhattacharya et al. (2010) argued that there has been widespread criticism that accounting does not provide useful information to assist investors in decisions. In the same context, Mohan \& John (2011) stated that the value relevance of accounting information has been increasingly criticized because investors lost their trust in accounting information having in minds the cases of Enron, WorldCom. While, Robu (2015) stated that the investor confidence in the accounting information has suffered because of the unfavorable economic conditions, marked by economic and financial crises and financial fraud.

For a long time there was a continuous debate between accountants and users about the importance of accrual measures (e.g., Earning) and cash measures for users as the best accounting indicator for companies performance. This debate continues to affect the way how researchers study the value relevance of accounting information in literatures. The majority of previous studies (e.g., Naceur \& Goaied 2004, Al-Attar \& Al-Khadash 2005, Abu-Nassar \& Al-Thnaibat 2005, Hamdan et al. 2008, Bepari et al. 2013, Hajjaj \& Al-Debi'e 2014) addressed the value relevance issues by comparing the value relevance of accrual signals vs. cash signals. Drake et al. (2015) comment on this by stating that the impact of accounting information on stock markets is often based on the relation between accounting signals and changes in measures of trading activity, such as stock returns or trading volume. Another way on how researchers study the value relevance of accounting information was by comparing the value relevance of the financial statements (e.g., income statement, balance sheet, and cash flows statement) as the most relevant source of information for decision making (e.g., Al-Hanini 1994, Alattar \& Al-Khater 2007, Al-hussain 2007). In this regard, Klimczak \& Szafranski (2013) stated that the relevance of financial statement information for the valuation of corporate equity in financial markets is one of the core research problems in accounting.

This study extends previous studies in the field of the value relevance of accounting information for investors' decisions, especially Obaidat (2016) and Mohan \& John (2011) studies. Obaidat (2016) study assessed the value relevance of accounting information for investment decisions and investigated if investors demographic and behavioral factors affect this value relevance in Amman Stock Exchange (ASE). The results revealed that individual investors perceive accounting information to be value relevant regardless of their demographic and behavioral factors. The study recommends further studies to address the value relevance of accounting information signals (e.g., earning, cash flows) in details. While, Mohan \& John (2011) study investigated the value relevance of accounting information in India and found that the book value per share and earnings per share are value relevant to investment decisions. Mohan \& John (2011) study suggested further research to find out the value relevance of other accounting signals, such as cash flow and earnings components in India and other countries.

This study aimed to extend pervious studies concerning the value relevance of accounting information for investment decisions by investigating which accounting information is considered more value relevant emphasizing the comparison between earning and cash flow information. In addition, the study aimed to examine if individual investors have the time and abilities to assess the value relevance of accounting information. And finally, this study aimed to measure the degree of consensus among different types of investors concerning the issues investigated. The remainder of the paper is organized as follows; section two presents the previous literature on the subject; section three provides a brief history of Amman Stock Exchange (ASE) in Jordan; section four describes data collection process, study variables, hypotheses to be tested and statistical techniques adopted; section five discusses study results and section six presents study conclusions and limitation.

\section{Literature Review}

El Shamy \& Kayed (2005) study investigated the value relevance of accounting information based on International Accounting Standards (IAS) in equity valuation in the Kuwaiti Stock Exchange. The results indicated that accounting information based on IAS is relevant in equity valuation. Bhattacharya et al. (2010) Study showed that prior studies indicated that accounting information is relevant for stock valuation, failure prediction, performance evaluation, optimal contracting, and other decision-making contexts in relatively stable markets. Jianu et al. (2014) study stated that there were only few studies concerning the value relevance of accounting information on the emerging markets. And the result indicated that accounting information is value relevant to investors in the Romanian Stock Market despite the young age of the market. In addition, the results confirmed that improving accounting rules lead to increasing the relevance of accounting information. A recent study by Farj et al. (2016) investigated the value relevance of accounting information contained in the corporate annual reports published in the Libyan Stock Market 
from the perspective of investors. The result indicated that corporate financial reports are useful despite the fact that they are not the most important source of information influencing investors' decisions because Libyan investors depend mainly on the advice obtained from brokers. The study concluded that this result is due to inadequate information contained in corporate financial reports in terms of quantity and quality.

Concerning the debate about earning and cash flows signals, Naceur \& Goaied (2004) study investigated the value-relevance of the major corporate financial variables for Tunisian listed companies for investment decisions. This paper reported that earnings, book value and dividends are value-relevant. Al-Attar \& Al-Khadash (2005) study aimed to determine which are better earnings or cash flows as a performance measure for companies listed in Amman Stock Exchange (ASE). The study provides evidence on the value relevance of cash flow figures for investors in their investment decisions. Abu-Nassar \& Al-Thnaibat (2005) study aimed to investigate the importance of disclosure requirements related to the periodic financial statements of the Jordanian public share-holding companies according to the views of the external auditors, preparers of financial statements and investors. The results showed that among 49 disclosure items, the study investigated, earning came first in investor priority followed by cash flows information. Hamdan et al. (2008) study examined the relationship of earnings and operating cash flows with stock returns. The study revealed that earnings are considered the important variable in ASE, while the role of operating cash flows is weak, because they are influenced by timing and matching problems that cause them to be noisy measures of firm performance. Bepari et al. (2013) study findings suggested that earnings have greater relative and incremental information content than cash flow from operations (CFO) in the Australian market. And this is because earnings contain timely information that reflects the changes in firms' performances due to its matching attributes. While, due to the inherent limitations of CFO in terms of matching revenues with expenses and losses, CFO lacks timely information that reflect firms' performances. Also the study concluded that the incremental value relevance of earnings and CFO in the normal economic condition is conditional on different factors which may not generalize to other economic do not operate in normal conditions such as economic shocked by the financial crisis. A related result is Hajjaj \& Al-Debi'e (2014) study that showed that investors use most of financial statements signals (e.g. finished goods, gross profit, and capital expenditures) in investment decisions and the perception of the importance of these signals vary according to the prevailing economic conditions.

Concerning the value relevance of financial statements, Al-Hanini (1994) study aimed to determine the accounting information that affects investors' decisions in ASE. The results indicated that investors rank the balance sheet statement first followed by the income statement as the most important sources of information. In addition, the results also indicated that investors are interested in company dividends policy and financial ratios. Alattar \& Al-Khater (2007) showed that the results from previous studies revealed that users of annual reports generally regarded annual financial reports as important sources of information and income statement data was regarded as a primary information source, while liquidity was regarded as secondary material when analyzing corporate results. Al-hussain (2007) study aimed to examine to what extent Saudi stock market investors depend on accounting information for investment decision and to identify the most important sources of information. The results indicated that investors rank the income statement first followed by the balance sheet statement then by the cash flows statement and finally the auditor report as the most important sources of information. In addition, the results indicated that investors are interested in company dividends policy, accounting policies and financial ratios.

Previous literatures also studied other accounting variables that are value relevant to investors' decisions. For instance, Baker \& Haslem (1974) study revealed that there are three meaningful variables that cause investors to vary in their perceptions of the desirability of specific stocks. These variables were: dividends, future expectations and financial stability. Antonio (2003) results showed that users of accounting information consider auditor report to be value relevant when making investing and financing decisions. Dar-Mousa (2006) study aimed to explore the financial ratios used by investors at ASE when making investment decisions, and found that the profitability ratios (earning per share, return on asset and gross margin) were the most important ratios for investment decisions, followed by dividends ratio then by debt ratios. Salah (2010) study aimed to identify the informational content of published financial statements in ASE, and how it supports investment and lending decisions. The study revealed that the study sample, including investors, considered notes attached to the financial statements as the most important source of information for decisions. While, the cash flows statement information came last. Ashrafi \& Muhammad (2013) study showed that institutional investors in Malaysia invest in firms with large size, more tangible assets, more ROA, more growth, less stock price volatility, less leverage, less managerial ownership and less business risk. The investors prefer to invest in large firms with the belief that they have a low risk of bankruptcy. Al-Habashneh et al. (2015) study recommended investors to focus on the variables of dividends, trading volume and earnings per share when they take their decision to invest in ASE, because these variables have a positive effect on the stock price. 


\section{A Brief History of Amman Stock Exchange (ASE)}

Public shareholding companies were set up and their shares were traded in, long before the setting up of the Jordanian Securities Market. In the early thirties, the Jordanian public already subscribed to and traded in shares; the Arab Bank was the first public shareholding company to be established in Jordan in 1930, followed by Jordan Tobacco and Cigarettes in 1931, Jordan Electric Power in 1938, and Jordan Cement Factories in 1951. In 1975 and 1976, the Jordanian Central Bank conducted intensive studies, in cooperation with the International Finance Corporation (IFC), and it became clear that the size of the national economy and the share of the private sector in it through public shareholding companies and its broad investor base justified such a step. These joint efforts resulted in the issuance of the temporary law No. 31 of the year 1976, and the establishment of Amman Financial Market (AFM) which started to operate on January 1, 1978. At that time, it was the leading securities market in the region. Since that, the AFM played the role as a regulatory body of the stock exchange and operated according to the international standards. The issuance of the Securities Law No. 23 in 1997 was indeed a landmark and a turning point for the Jordanian capital market. The main purposes for the issuance of this low were: separating regulatory function from trading function; restructuring the market in accordance with international standards; creating the legal framework for the issuance of new financial instruments; encouraging, attracting and protecting investors; establishing a transparent and fair market. In 1997 AFM have emerged out to three institutions: the Jordan Securities Commission (JSC), the Amman Stock Exchange (ASE) and the Securities Depository Center (SDC). Concerning quantitative development of the securities market; market capitalization increased from 403 million (US \$) in 1978 to more than 24 billion (US \$) at the end of 2015; the trading volume increased from 13.6 million (US \$) in 1978 to 3.5 billion (US \$) at the end of 2015; and the number of listed companies increased from 66 companies in 1978 to 228 companies at the end of 2015. The Jordanian government adopted a comprehensive capital market reforming policy, which aimed to: boost the private sector, expand and diversify the national economy, and improve regulations of the securities market to reach the international standards. Also, among the most important features of the new orientation were institutional changes in the capital market such as: the use of international electronic trading, the use of settlement and clearance systems, elimination of obstacles to investment, and strengthening capital market supervision (Jordan Security Commission, Amman Stock Exchange).

\section{Research Method}

\subsection{Data Instrument and Study Sample}

A questionnaire was used as an instrument to collect data. A random sample was drawn from individual investors in ASE. The researcher depended on the previous literature and his own experience to develop the questionnaire. Several academicians were consulted to assess the construct and content validity of the questionnaire. 165 questionnaires were distributed to individual investors in ASE. Only 104 questionnaires were collected, 3 of them were excluded because they were fully or partially uncompleted, which means that this study is based on 101 usable questionnaires, and this reflects $61 \%$ response rate. All questionnaires was delivered by hand by the researcher and in some cases the questionnaire was discussed with the investors when they required help to ensure that investors understood all questions, and answered them truthfully.

\subsection{Study Variables}

A list of potential accounting information required by investors was included in the questionnaire. Most items in the list were extrapolated from previous studies and some items supposed to be value relevant were added depending on the researcher's experience. The list was made as short as possible in order to obtain a high response rate (see, Al-Ajmi 2009). Investors were asked to determine the value relevance of the accounting information included in the list when they took the decisions of buying, holding and selling stocks in ASE. The questionnaire includes three sections with a well-designated covering letter. All questions of the questionnaire are close-ended. The first section includes eight questions concerning demographic and general information for investors and their investment. The questions in this section were extrapolated from Obaidat (2016) study; the second section includes the list of potential accounting information required by investors. The list includes fourteen items and the investors were asked to express their opinions about the value relevance of each item in the list using a five-point Likert scale with 1 signifying "not relevant at all", 2 signifying "slightly relevant", 3 signifying "moderately relevant", 4 signifying "relevant", and 5 signifying "very relevant"; the third section includes two questions asking the investors if they have time and abilities to assess the accounting information when they take their decisions. Also, a five-point Likert scale was used in this section with 1 signifying "strongly disagree", 2 signifying "disagree", 3 signifying "neutral", 4 signifying "agree", and 5 signifying "strongly agree". 


\subsection{Hypotheses}

Based on the previous discussion, the following hypotheses were developed:

H1: From individual investors' perspective, the value relevance of earning information is superior to the value relevance of cash flow information.

$\mathrm{H} 2$ : Individual investors have enough time to assess the accounting information.

H3: Individual investors have the abilities and knowledge to assess the accounting information.

Table 1. Demographic and Descriptive Statistics

\begin{tabular}{|c|c|c|c|c|c|}
\hline \multicolumn{6}{|l|}{$\underline{\text { Sex }}$} \\
\hline & Male & Female & & & \\
\hline No. & 81 & 20 & & & \\
\hline$\%$ & $80.2 \%$ & $19.8 \%$ & & & \\
\hline \multicolumn{6}{|c|}{ Education level } \\
\hline & $\underline{\text { High school }}$ & Diploma & $\underline{B . A}$. & M.A. & $\underline{P h . D .}$. \\
\hline No. & 11 & 15 & 64 & 7 & 4 \\
\hline$\%$ & $10.9 \%$ & $14.9 \%$ & $63.4 \%$ & $6.8 \%$ & $4 \%$ \\
\hline \multicolumn{6}{|c|}{ University major } \\
\hline & Business & Other & & & \\
\hline No. & 57 & 44 & & & \\
\hline$\%$ & $56.4 \%$ & $43.6 \%$ & & & \\
\hline \multicolumn{6}{|c|}{ Investment period (in years) } \\
\hline & $\leq 5$ & $\underline{6-10}$ & $\underline{11-15}$ & $\underline{15-20}$ & $\geq 20$ \\
\hline No. & 21 & 40 & 22 & 6 & 12 \\
\hline$\%$ & $20.8 \%$ & $39.6 \%$ & $21.8 \%$ & $5.9 \%$ & $11.9 \%$ \\
\hline \multicolumn{6}{|c|}{ Portfolio size measured by amount invested (in thousand US. Dollars) } \\
\hline & $\leq 35$ & $\underline{35-70}$ & $\underline{71-105}$ & $106-141$ & $\geq 141$ \\
\hline No. & 62 & 20 & 8 & 4 & 7 \\
\hline$\%$ & $61.4 \%$ & $19.8 \%$ & $7.9 \%$ & $4 \%$ & $6.9 \%$ \\
\hline \multicolumn{6}{|c|}{ Portfolio size measured number of companies investing in } \\
\hline & $\leq \mathbf{5}$ & $\underline{6-10}$ & $\underline{11-15}$ & $\underline{16-20}$ & $\geq 20$ \\
\hline No. & 45 & 33 & 10 & 3 & 10 \\
\hline$\%$ & $44.6 \%$ & $32.7 \%$ & $9.9 \%$ & $3 \%$ & $9.8 \%$ \\
\hline \multicolumn{6}{|c|}{$\underline{\text { Nature of investment }}$} \\
\hline & Short term & Long term & & & \\
\hline No. & 66 & 35 & & & \\
\hline$\%$ & $65.3 \%$ & $34.7 \%$ & & & \\
\hline \multicolumn{6}{|c|}{ Monthly trading frequency } \\
\hline & $\leq 5$ & $\underline{6-10}$ & $\underline{11-15}$ & $\underline{16-20}$ & $\geq 20$ \\
\hline No. & 32 & 32 & 13 & 9 & 15 \\
\hline$\%$ & $31.7 \%$ & $31.7 \%$ & $12.9 \%$ & $8.9 \%$ & $14.8 \%$ \\
\hline
\end{tabular}

\section{Results and Discussion}

\subsection{Demographic and Descriptive Statistics}

Table 1 shows the demographic and general information of the study sample. As shown, $80.2 \%$ of the sample was male, indicating a low participation of females in the investment process in ASE. Regarding education, $14.9 \%$ of the sample have a diploma, $63.4 \%$ have B.A., $6.8 \%$ have M.A., and $4 \%$ of them have Ph.D. Also, regarding education, the result shows that more than half of the sample (56.4\%) have a university certification in business majors (e.g., Accounting, Management, Finance, and Economics). This percentage indicates that a considerable percentage of investors are familiar with accounting and accounting information. Concerning investors experience in the stock market, the result shows that $20.8 \%$ of the sample have investment experience in stock market for less than five years, $39.6 \%$ of them between five and ten years, $21.8 \%$ of them between eleven and fifteen years, $17.8 \%$ of them have investment experience for more than fifteen years. As for portfolio size in amount, the majority of the sample $61.4 \%$ are currently investing less than $(35,000 \$), 19.8 \%$ of them investing between $(70,000 \$)$ and $(105,000 \$)$, and only 
$18.8 \%$ of them investing more than $(105,000 \$)$, which means that the majority of individual investors in ASE are small investors and this concurs with Obaidat (2016) study. In the same context and concerning portfolio size, measured by a number of companies, the results indicated that $44.6 \%$ of the sample is currently investing in less than five companies, $32.7 \%$ of them investing in more than five companies but not more than ten companies, $9.9 \%$ of them investing in more than ten companies but not more than fifteen companies, while the rest (12.8\%) are investing in more than fifteen companies. Merton (1987) cited in Obaidat (2016) notes that individual investors tend to hold only few different stocks in their portfolios due to the difficulty of gathering information about several numbers of different stocks. In this regard, Battalio \& Mendenhall (2005) cited in Frederickson \& Zolotoy (2016) stated that institutional investors have greater resources available to them, suggesting that they can attend to and process a larger volume of information in a given period of time than can individual investors. According to the result of the nature of investment, $65.3 \%$ of the sample indicated that their investment is short term. While the rest $(34.7 \%)$ indicated that their investment is long term. Also, this result agrees with Obaidat (2016) study that revealed convergent percentages. Finally, the results show that $31.7 \%$ of the sample make less than five trading transaction monthly, and the same percentage (31.7\%) make more than five but not more ten transactions monthly, while $12.9 \%$ of them make more than ten but not more than fifteen transactions monthly, and the rest $(23.7 \%)$ make more than fifteen transactions monthly. Although the result indicated that most investors in the sample $(65.3 \%)$ stated that their investment is a short term, which means they aim to achieve income from day-to-day stock price differences and this in turn should be reflected on high trading frequencies per month. But on the contrary to this, the result shows a low trading frequency and this could be attributed to the results of portfolio size which indicated that the investors hold only few different stocks in their portfolios.

\subsection{Hypotheses Testing}

Table 2 shows the ranks and mean importance scores that investors accorded to the accounting information supposed to be value relevant to their decisions. As shown, the means for all items are significant, which means that individual investors perceive all accounting information listed in the table to be value relevant for investment decisions. A previous study by Alattar \& Al-Khater (2007) revealed that all sections of the financial statements were considered value relevant for investment decision making by users in Qatar Stock Market. Alattar \& Al-Khater (2007) comment on this by stating that this results support the view that all information contents in the financial statements are considered to be complementary to each other. Although all items in Table 2 are considered value relevant for investment decisions, the importance of each item varies. As unexpected, the financial risk came first as the most value relevant information, while the previous earning came second, followed by liquidity, then by expected earning, then by market stock price and then by the stability of dividend and earning. While the cash flow information came last.

Table 2. One Sample T-test Results for Accounting Information Value Relevance

\begin{tabular}{|c|c|c|c|c|c|c|c|}
\hline \multirow[t]{2}{*}{$\underline{\text { Rank }}$} & \multirow[t]{2}{*}{$\underline{\text { Item }}$} & \multirow[t]{2}{*}{$\underline{\text { Mean }}$} & \multirow[t]{2}{*}{$\frac{\text { Std. }}{\underline{\text { Dev. }}}$} & \multirow[t]{2}{*}{$\underline{\mathbf{t}}$} & \multirow[t]{2}{*}{ Sig. } & \multicolumn{2}{|c|}{$\begin{array}{l}\text { 95\% Confidence } \\
\text { Interval of the } \\
\text { Difference }\end{array}$} \\
\hline & & & & & & Lower & Upper \\
\hline 1 & Financial risk. & 4.3069 & 0.94597 & 45.757 & 0.000 & 4.1202 & 4.4937 \\
\hline 2 & Previous earning. & 4.2376 & 0.83843 & 50.794 & 0.000 & 4.0721 & 4.4031 \\
\hline 3 & Liquidity. & 4.2277 & 0.83524 & 50.869 & 0.000 & 4.0628 & 4.3926 \\
\hline 4 & Expected earning. & 4.1881 & 0.84514 & 49.803 & 0.000 & 4.0213 & 4.3550 \\
\hline 5 & Market stock price. & 4.1287 & 0.90181 & 46.011 & 0.000 & 3.9507 & 4.3067 \\
\hline 6 & Stability of dividend. & 4.1188 & 0.90870 & 45.552 & 0.000 & 3.9394 & 4.2982 \\
\hline 7 & Stability of earning. & 4.0792 & 0.93470 & 43.860 & 0.000 & 3.8947 & 4.2637 \\
\hline 8 & Expected dividend. & 4.0693 & 0.99255 & 41.203 & 0.000 & 3.8734 & 4.2652 \\
\hline 9 & Previous dividends. & 3.9703 & 0.99454 & 40.120 & 0.000 & 3.7740 & 4.1666 \\
\hline 10 & Financial ratios. & 3.9208 & 0.96626 & 40.779 & 0.000 & 3.7300 & 4.1115 \\
\hline 11 & Auditor report. & 3.8218 & 1.10812 & 34.661 & 0.000 & 3.6030 & 4.0405 \\
\hline 12 & Total assets. & 3.8119 & 1.06502 & 35.970 & 0.000 & 3.6016 & 4.0221 \\
\hline 13 & Expected cash flows. & 3.7228 & 0.99115 & 37.748 & 0.000 & 3.5271 & 3.9184 \\
\hline 14 & Previous cash flows. & 3.6733 & 0.92854 & 39.757 & 0.000 & 3.4900 & 3.8566 \\
\hline
\end{tabular}


As the previous and expected earning information came in the second and fourth ranks with a means of (4.2376) and (4.1881) respectively as the most value relevant information. While the expected and pervious cash flows information came in the last ranks with a means of (3.7228) and (3.6733) respectively, Paired Sample T-test was performed to test if the difference between the value relevance means of earning information and the value relevance means of cash flow information is statistically different. As Table 3 illustrates: the difference between the value relevance means of previous earning and previous cash flows is significant; the difference between the value relevance means of previous earning and expected cash flows is significant; the difference between the value relevance means of expected earning and the previous cash flows is significant; and finally the difference between the value relevance means of expected earning and expected cash flows is also significant. This means that the value relevance of earning information is superior to the value relevance of cash flow information. So, the first hypothesis is accepted. This result concurs with previous studies such as: Abu-Nassar \& Al-Thnaibat (2005) study that found that earning came first in investors priority followed by cash flows information in ASE, Hamdan et al. (2008) study that revealed that earnings are considered the important variable in ASE, while the role of operating cash flows is weak and Bepari et al. (2013) study that found that earnings have greater relative and incremental information content than cash flow from operations in the Australian market.

Table 3. Paired Sample T-test results for the first hypothesis

\begin{tabular}{cccccccccc}
\hline$\underline{\text { Item }}$ & Mean & $\underline{\underline{\text { Std. }}}$ & $\underline{\text { Dev. }}$ & $\underline{\mathbf{t}}$ & $\underline{\text { df }}$ & $\underline{\underline{\text { Sig. }}}$ & $\begin{array}{c}\text { 95\% Confidence } \\
\text { Interval of the } \\
\text { Difference } \\
\text { Lower }\end{array}$ & $\underline{\text { Upper }}$ \\
\hline Pair & $\begin{array}{c}\text { Previous Earning } \\
\text { Previous Cash Flows }\end{array}$ & 0.5643 & 0.94251 & 6.018 & 100 & 0.000 & 0.37829 & 0.75042 \\
Pair & $\begin{array}{c}\text { Previous Earning } \\
\text { Expected Cash Flows } \\
\text { Pair }\end{array}$ & 0.5148 & 1.08272 & 4.779 & 100 & 0.000 & 0.30111 & 0.72859 \\
Pair & $\begin{array}{c}\text { Prected Earning } \\
\text { Expected Earning } \\
\text { Expected Cash Flows }\end{array}$ & 0.5148 & 1.04512 & 4.951 & 100 & 0.000 & 0.30853 & 0.72117 \\
\hline
\end{tabular}

It is obvious that the main three value relevant items of information for individual investors in ASE were the risk, earning and liquidity. Thereby it can be argued that investors have a comprehensive view about the most important signals to evaluate companies' performance. Bebeşelea (2014) comment on this by stating that the investors want to measure the profitability and risk of their investments, to make the decision whether to maintain, increase or diminish their contributions.

On the other hand, some pervious studies concur with the results regarding the other accounting information items that came in moderate ranks according to their value relevance to investors. For example, Baker \& Haslem (1974) study revealed that dividends, future expectations and financial stability were the most meaningful variables to investors when taking decisions, Antonio (2003) study showed that users of accounting information consider auditor report to be value relevant when making investing and financing decisions, Dar-Mousa (2006) study found that ratios are considered very important for investment decisions, where the profitability ratios came first followed by dividends ratio then by debt ratios, Ashrafi \& Muhammad (2013) study showed that investors prefer to invest in large firms because they believe that large firms have a low risk of bankruptcy, Al-Habashneh et al. (2015) study found that dividends and EPS ratio have a positive effect on the stock price.

It is known that the qualitative characteristic of accounting information (relevance) is linked to the users' (investors') characteristic (understandability). In other words, if the accounting information is value relevant but the investor does not have the time or abilities to assess this information it will lose its relevance value. So, after examining what accounting information is perceived to be value relevant to individual investors, it is important to go to the next step to examine if the investors have the time and abilities to assess this accounting information. The second hypothesis stated that "Individual investors have enough time to assess the accounting information", while the third hypothesis stated that "Individual investors have the abilities and knowledge to assess the accounting information". Table 4 shows the statistical results for the second and third hypotheses. As shown, the mean for the second hypothesis is (3.7228) and it is statistically significant. While the mean for the third hypothesis is (3.9109) and it is also statistically significant. Accordingly, the second and third hypotheses are accepted, which means that individual 
investors have the time and abilities to assess the accounting information for investment decisions. Two important facts justify these results: first, more than half of the investors (56.4\%) have a university certification in business majors which means that they are familiar with accounting information and face no problem in assessing such information. Second, the majority of investors $(87.2 \%)$ are currently having less than fifteen companies in their portfolios and a considerable percentage of them $(76.3 \%)$ make less than fifteen trading transactions monthly. So they do not need a lot of time and effort to gather accounting information and assess it for a few numbers of companies and transactions. In this context, two previous studies in Jordan revealed that investors in ASE understand all accounting information included in the financial reports (Abu-Nassar \& Rutherford 1996, Mashoka 2013).

Table 4. One Sample T-test results for the Second and Third hypotheses

\begin{tabular}{|c|c|c|c|c|c|c|}
\hline \multirow[t]{2}{*}{ Hypothesis } & \multirow[t]{2}{*}{$\underline{\text { Mean }}$} & \multirow[t]{2}{*}{ Std. Dev. } & \multirow[t]{2}{*}{$\underline{\mathbf{t}}$} & \multirow[t]{2}{*}{$\underline{\text { Sig. }}$} & \multicolumn{2}{|c|}{$\begin{array}{l}95 \% \text { Confidence Interval of } \\
\text { the Difference }\end{array}$} \\
\hline & & & & & Lower & Upper \\
\hline Enough time to assess the accounting information & 3.7228 & 0.84993 & 44.020 & 0.000 & 3.5550 & 3.8906 \\
\hline Abilities and knowledge to assess the accounting information & 3.9109 & 0.70851 & 55.474 & 0.000 & 3.7710 & 4.0508 \\
\hline
\end{tabular}

Table 5. Independent Sample T-test Results

\begin{tabular}{|c|c|c|c|c|c|c|c|c|c|c|}
\hline \multirow[b]{3}{*}{ Item } & \multicolumn{5}{|c|}{ Investors Background (University major) } & \multicolumn{5}{|c|}{ Investment Nature } \\
\hline & \multicolumn{2}{|c|}{ Business } & \multicolumn{2}{|c|}{ Other } & \multirow[b]{2}{*}{ Sig. } & \multicolumn{2}{|c|}{ Sort-term } & \multicolumn{2}{|c|}{$\underline{\text { Long-term }}$} & \multirow{2}{*}{$\underline{\text { Sig. }}$} \\
\hline & Mean & Rank & Mean & Rank & & Mean & Rank & Mean & $\overline{\text { Rank }}$ & \\
\hline$\overline{\text { Previous earning. }}$ & $\overline{4.3684}$ & 1 & $\overline{4.0682}$ & 6 & 0.074 & $\overline{4.1818}$ & 2 & $\overline{4.3429}$ & 2 & 0.361 \\
\hline Expected earning. & 4.2281 & 2 & 4.1364 & 4 & 0.591 & 4.1667 & 4 & 4.2286 & 7 & 0.728 \\
\hline Previous dividends. & 4.0526 & 9 & 3.8636 & 10 & 0.346 & 3.8636 & 10 & 4.1714 & 9 & 0.140 \\
\hline Expected dividend. & 4.1579 & 5 & 3.9545 & 9 & 0.310 & 3.9697 & 8 & 4.2571 & 5 & 0.167 \\
\hline Previous cash flows. & 3.6491 & 14 & 3.7045 & 14 & 0.768 & 3.6212 & 14 & 3.7714 & 13 & 0.442 \\
\hline Expected cash flows. & 3.7193 & 13 & 3.7273 & 13 & 0.968 & 3.6667 & 13 & 3.8286 & 12 & 0.437 \\
\hline Stability of earning. & 4.1228 & 7 & 4.0227 & 7 & 0.596 & 4.0152 & 6 & 4.2000 & 8 & 0.347 \\
\hline Stability of dividend. & 4.1404 & 6 & 4.0909 & 5 & 0.788 & 3.9848 & 7 & 4.3714 & 1 & $* 0.041$ \\
\hline Liquidity. & 4.1930 & 4 & 4.2727 & 2 & 0.637 & 4.1818 & 2 & 4.3143 & 3 & 0.451 \\
\hline Financial risk. & 4.2281 & 2 & 4.4091 & 1 & 0.343 & 4.3182 & 1 & 4.2857 & 4 & 0.871 \\
\hline Market stock price. & 4.0702 & 8 & 4.2045 & 3 & 0.461 & 4.0606 & 5 & 4.2571 & 5 & 0.300 \\
\hline Financial ratios. & 3.8772 & 10 & 3.9773 & 8 & 0.608 & 3.9242 & 9 & 3.9143 & 10 & 0.961 \\
\hline Total assets. & 3.8421 & 12 & 3.7727 & 11 & 0.747 & 3.7727 & 12 & 3.8857 & 11 & 0.614 \\
\hline Auditor report. & 3.8772 & 10 & 3.7500 & 12 & 0.570 & 3.8485 & 11 & 3.7714 & 13 & 0.741 \\
\hline
\end{tabular}

\subsection{Additional Results}

This study measured the degree of consensus among different types of investors concerning the issues investigated to find if investors' types affect the value relevance perception. Accordingly, investors in this study were classified as either business investors (who have university certification in business) or other investors (who do not have university certification in business). Another classification of investors was short-term investor or long-term investor. Table 5 illustrates the ranks and importance means of the accounting information items according to each class of investors. As shown, business investors rank the pervious earning as the most value relevant item followed by the expected earning and risk in the second rank, then by liquidity and expected dividends. While the other investors rank risk first followed by liquidity, then by market stock price, then by expected earning. On the other hand, business investors and other investors agreed on the value relevance of cash flows information, where the expected and previous cash flows information came in the last two ranks. By comparing the results of short-term and long-term investors, it is obvious that short-term investors rank the risk first followed by the previous earning and liquidity in the second rank, followed by expected earning then by market stock price. Long-term investors rank the stability of dividends first followed by previous earning, then by liquidity, then by risk. The significant columns in the table indicated if the difference between means (ranks) of each pair of investors is significant. As shown, the only significant difference was between short-term and long-term investors concerning the stability of dividends. Long-term investors considered the stability of dividends as the most value relevant information for their decisions, while short-term investors rank it in the seventh rank, which means that long-term investors considered the stability of dividends more value relevant than short-term investors. This is considered a consequence of the long term investment purpose, because long-term investors aim to stay in the company for long time to get benefit from earning distributed as dividends, while short-term investors aim to sell the stock as soon as possible when the market stock price increases. In other words, there are other priorities for sort-term investors other than the stability of dividends. Concerning the stability of dividends, a local study by Al-Qaisi \& Omet (2010) covered the period between 1995 and 2005 revealed that the listed Jordanian companies follow stable dividends policies. 


\section{Conclusion and Limitation}

This study extends pervious studies concerning the value relevance of accounting information for investment decisions by investigating the accounting information that is considered more value relevant for individual investors in ASE, emphasizing the comparison between earning and cash flow information. The accounting information items tested was: previous and expected earning, previous and expected dividends, previous and expected cash flows, stability of earning and dividends, liquidity, financial risk, market stock price, financial ratios, total assets, and auditor report. In addition, the study examined if individual investors have the time and abilities to assess the accounting information and measured the degree of consensus among different types of investors concerning the issues investigated.

The results indicated that individual investors perceive all accounting information to be value relevant for investment decisions, which support the view that all information contents in the financial statements are considered to be complementary to each other and are needed by investors to draw a complete picture about firms' performance. The most value relevant information was financial risk followed by previous earning, liquidity, expected earning, market stock price, stability of dividend and stability of earning respectively. While the previous and expected cash flow information came in the last two ranks.

Whereas prior studies suggested that the value relevance of earnings information and cash flows information is conditional and vary from one country to another depending on firms' specific factors and economic conditions Bepari et al. (2013). The results concerning the comparison between them indicated that the value relevance of earning information is superior to the value relevance of cash flow information in ASE. This result supports most of pervious studies in Jordan (e.g., Abu-Nassar \& Al-Thnaibat 2005, Hamdan et al. 2008). On the other hand, this study documented that individual investors have the time and abilities to assess the accounting information for investment decisions. Two important facts justify these results: first, more than half of the investors (56.4\%) have a university certification in business majors which means that they are familiar with accounting information and face no problem in assessing such information. Second, the majority of investors (87.2\%) currently have less than fifteen companies in their portfolios and a considerable percentage of them (76.3\%) make less than fifteen trading transactions monthly. So they do not need a lot of time and effort to gather accounting information and assess it for a few numbers of companies and transactions.

To measure the degree of consensus among different types of investors concerning the issues investigated, investors were classified as either business investors (who have university certification in business) or other investors (who do not have university certification in business). The second classification was short-term investor or long-term investor. The result shows that there is a consensus between business investors and other investors concerning the value relevance of accounting information items. The result also shows that there is a consensus between short-term investors and long-term investors for all items except for the stability of dividends. Whereas, the long-term investors valued the stability of dividends more than the short-term investors and considered it as the most value relevant information for investment decisions, while the short-term investors rank it as the seventh value relevant information indicating other priorities for sort-term investors other than the stability of dividends such as earning and market stock price.

Finally, this study is subject to the limitation of the small number of respondents. Although the researcher made every effort to increase the number of respondents, Only 101 useable questionnaires were collected. And this is due to the fact that most of the individual investors in ASE are not cooperative with researchers. Most studies in ASE suffered from this problem, for example: Al-Hanini (1994) study includes 50 investors, Abu-Nassar \& Al-Thnaibat (2005) study includes 43 investors and Dar-Mousa (2006) study includes 83 investors.

\section{References}

Abu-Nassar, M., H. \& Al-Thnaibat, A., A. (2005). Importance of Disclosure Requirements Issued by Securities Exchange Commission, and their Adequacy for Serving Users of Financial Statements. Dirasat, Administrative Sciences, 32(1), 115-141.

Abu-Nassar, M. H. \& Rutherford B. (1996). External Users of Financial Reporting in Less Developed Countries: The Case of Jordan. British Accounting Review, 28(1), 73-87. http://dx.doi.org/10.1006/bare.1996.0004

Al-Ajmi, J. (2009). Investors' use of corporate reports in Bahrain. Managerial Auditing Journal, 24(3), 266-289. http://dx.doi.org/10.1108/02686900910941140

Al-Attar, A. \& Al-Khadash, H. (2005). The Effect of Contextual Factors on the Information Content of Cash Flows in Explaining Stock Prices - The Case of Amman Stock Exchange -. Jordan Journal of Business Administration, 
1(1), 121-132.

Alattar, J., M. \& Al-Khater, K. (2007). An Empirical Investigation of Users' Views on Corporate Annual Reports in Qatar. International Journal of Commerce \& Management, $17(4), \quad 312-325$. http://dx.doi.org/10.1108/10569210710844381

Al-Habashneh, F., Shhateet, M., Al-Bdore, J. \& Amareen, Z. (2015). Factors Influencing the Share Price in Amman Stock Exchange During the Period (1984-2011). Dirasat, Administrative Sciences, 42(2), 461-472.

Al-Hanini, E. (1994). Accounting Information Which Affect Investors` Decisions in Amman Financial Market. Unpublished Master Thesis. The University of Jordan, Jordan.

Al-hussain, A., H. (2007). The Dependent of Investors in Saudi Stocks Market on Accounting Information When Making Investment Decision. Unpublished Master Thesis. The University of Jordan, Jordan.

Al-Qaisi, K., M. \& Omet, G., M. (2010). Dividend Policy at the Amman Stock Exchange: The Stability Issue During 1995-2005. Dirasat, Administrative Sciences, 37(1), 229-236.

Amman Stock Exchange. (n.d.). Retrieved from http://www.ase.com.jo

Antonio D., G., (2003). The Usefulness of The Audit Report in Investment and Financing Decisions. Managerial Auditing Journal, 18(6\&7), 549-559.

Ashrafi, M. \& Muhammad, J. (2013). The Preferences of Malaysian Institutional Investors: do They Change Their Preferences During Time?. International Journal of Business \& Society, 14 (3), 444-459.

Baker, H., K. \& Haslem, J. (1974). Toward The Development of Client-Specified Valuation Models. Journal of Finance, 29(4), 1255-1263. http://dx.doi.org/10.1111/j.1540-6261.1974.tb03102.x

Bebeşelea, M. (2014). Accounting Information and its Users. A Study of The Supply and Demand of Accounting Information in Romania. Economics, Management \& Financial Markets, 9 (4), 150-157.

Bepari, M., K., Rahman, S., F. \& Mollik, Abu T. (2013). Value Relevance of Earnings and Cash Flows During the Global Financial Crisis. Review of Accounting and Finance, 12(3), 226-251. http://dx.doi.org/10.1108/RAF-May-2012-0050

Bhattacharya, N., Demers, E. \& Joos, P. (2010). The Relevance of Accounting Information in a Stock Market Bubble: Evidence from Internet IPOs. Journal of Business Finance \& Accounting, 37(3\&4), 291-321. http://dx.doi.org/10.1111/j.1468-5957.2009.02144.x

Dar-Mousa, D. (2006). Accounting Factors Affecting the Decision of Investment in Jordanian Public Shareholding Companies Stocks. Unpublished Master Thesis. Alalbayt University, Jordan.

Drake, M., Roulstone, D. \& Thornock, J., R. (2015). The Determinants and Consequences of Information Acquisition via EDGAR. Contemporary Accounting Research, 32(3), 1128-1161. http://dx.doi.org/10.1111/1911-3846.12119

Ebaid, I., E. (2012). The value relevance of accounting-based performance measures in emerging economies - The case of Egypt. Management Research Review, 35(1), 69-88. http://dx.doi.org/10.1108/01409171211190814

El Shamy, M., A. \& Kayed, M., A. (2005). The value relevance of earnings and book values in equity valuation: An international perspective - The case of Kuwait. International Journal of Commerce and Management, 15(1), 68-79. http://dx.doi.org/10.1108/10569210580000188

Farj, R., M., H., Jais, M., B. \& Isa, A., H., B., M. (2016). Importance of Accounting Information to Investors in the Stock Market: A Case Study of Libya. IOSR Journal of Economics and Finance, 7(1), 70-79.

FASB (2010). Statement of Financial Accounting Concepts No. 8. Conceptual Framework for Financial Reporting. Page 17.

Francis, J. \& Schipper, K. (1999). Have Financial Statements Lost Their Relevance?. Journal of Accounting Research, 37(2), 319-352. http://dx.doi.org/10.2307/2491412

Frederickson, J., R. \& Zolotoy, L. (2016). Competing Earnings Announcements: Which Announcement Do Investors Process First?. Accounting Review, 91(2), 441-462. http://dx.doi.org/10.2308/accr-51190

Hajjaj, R., Y. \& Al-Debi'e, M., M. (2014). The Incremental Information Content of Financial Statements' Signals of Jordanian Industrial Shareholding Companies. Jordan Journal of Business Administration, 10(2), 199-228.

Hamdan, W., M., Gharaibeh, F., A. \& Al-Debi'e, M., M. (2008). The Role of Cash Flows and Accruals in Explaining 
stock Returns. Jordan Journal of Business Administration, 4(3), 288-310.

Hellström, K. (2006). The Value Relevance of Financial Accounting Information in a Transition Economy: The Case of the Czech Republic. European Accounting Review, 15(3), 325-349. http://dx.doi.org/10.1080/09638180600916242

Huian, M., C. (2015). The Usefulness of Accounting Information on Financial Instruments to Investors Assessing Non-Financial Companies. An Empirical Analysis on The Bucharest Stock Exchange. Accounting \& Management Information Systems, 14(4), 748-769.

IFRS (2015). Exposure Draft of Conceptual Framework for Financial Reporting. ED/2015/3. Page 28.

Jianu, I., Jianu, I., Ileanu, Bogdan V., Nedelcu, Monica V. \& Herteliu, C. (2014). The Value Relevance of Financial Reporting in Romania. Economic Computation \& Economic Cybernetics Studies \& Research, 48(4), 159-174.

Jordan Security Commission. (n.d.). Retrieved from http://www.jsc.gov.jo

Klimczak, K., M. \& Szafranski, G. (2013). Coincident and Forecast Relevance of Accounting Numbers. Accounting Research Journal, 26(3), 239-255. http://dx.doi.org/10.1108/ARJ-09-2012-0076

Mashoka, T., Z. (2013). The Relationship Between Earnings and Stock Returns on the Market and Sector Levels. Dirasat, Administrative Sciences, 40(2), 555-564. http://dx.doi.org/10.12816/0002657

Menaje, Jr., P., M. (2012). Impact of Selected Accounting and Economic Variables on Share Price of Publicly Listed Banks in the Philippines from 2002-2008. DLSU Business \& Economics Review, 22(1), 35-62.

Mohan, N. \& John, F. (2011). Value Relevance of Accounting Information - An Indian Perspective. Journal of Finance, Accounting \& Management, 2(1), 1-11.

Naceur, S., B. \& Goaied, M. (2004). The Value Relevance of Accounting and Financial Information: Panel Data Evidence. Applied Financial Economics, 14(17), 1219-1224. http://dx.doi.org/10.1080/0960310042000203019

Obaidat, A., N. (2016). The Value Relevance of Accounting Information in Emerging Stock Exchange Markets "Case of Jordan". Research Journal of Finance and Accounting, 7(12), 184-196.

Panagiotis, E., D. \& Dimitrios A. (2009). The Value Relevance of Financial Statements and Their Impact on Stock Prices: Evidence From Greece. Managerial Auditing Journal, 24(3), 248-265. http://dx.doi.org/10.1108/02686900910941131

Robu, M., A. (2015). Study on Increasing Value Relevance of Accounting Information by IFRS. Audit Financiar, 13(123), 100-110.

Salah, A. (2010). The Informational Content of Published Financial Statements Issued by the Jordanian Industrial Public Shareholding Companies from the Investors and Lenders and External Auditors' Point of View. Unpublished Master Thesis. Middle East University, Jordan. 